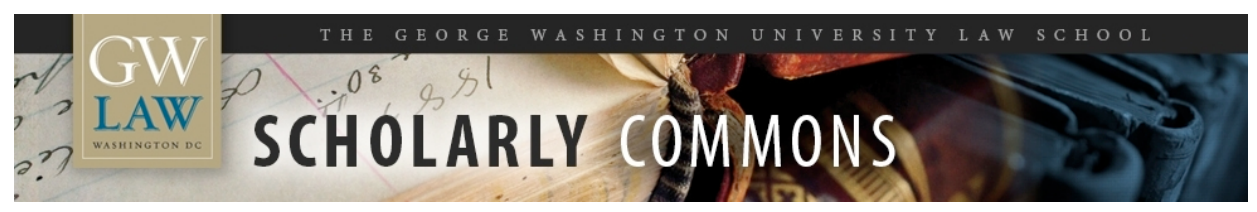

\title{
Including Law in the Mix: The Role of Law, Lawyers, and Legal Training in Child Advocacy
}

\author{
Catherine J. Ross \\ George Washington University Law School, cross@law.gwu.edu
}

Follow this and additional works at: https://scholarship.law.gwu.edu/faculty_publications

Part of the Law Commons

\section{Recommended Citation}

Catherine J. Ross, Including Law in the Mix: The Role of Law, Lawyers, and Legal Training in Child Advocacy, in 4 HANDBOOK OF APPLIED DEVELOPMENT SCIENCE 353 (Richard M. Lerner et al. eds., 2003).

This Chapter is brought to you for free and open access by the Faculty Scholarship at Scholarly Commons. It has been accepted for inclusion in GW Law Faculty Publications \& Other Works by an authorized administrator of Scholarly Commons. For more information, please contact spagel@law.gwu.edu. 


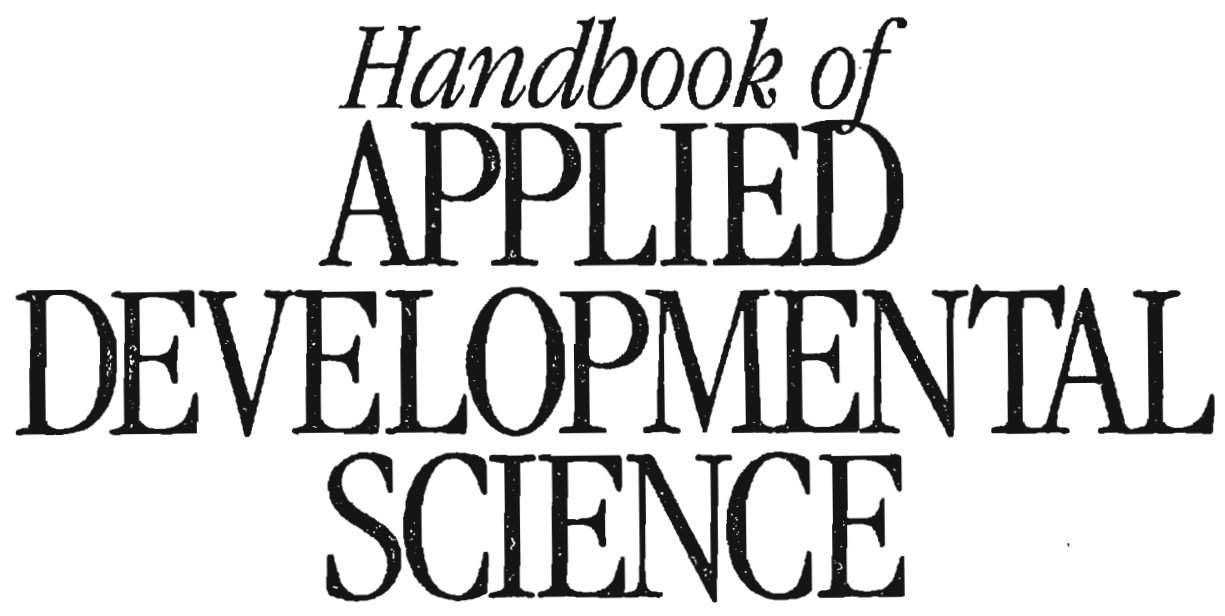

Promoting Positive Child, Adolescent, and Family Development Through Research, Policies, and Programs

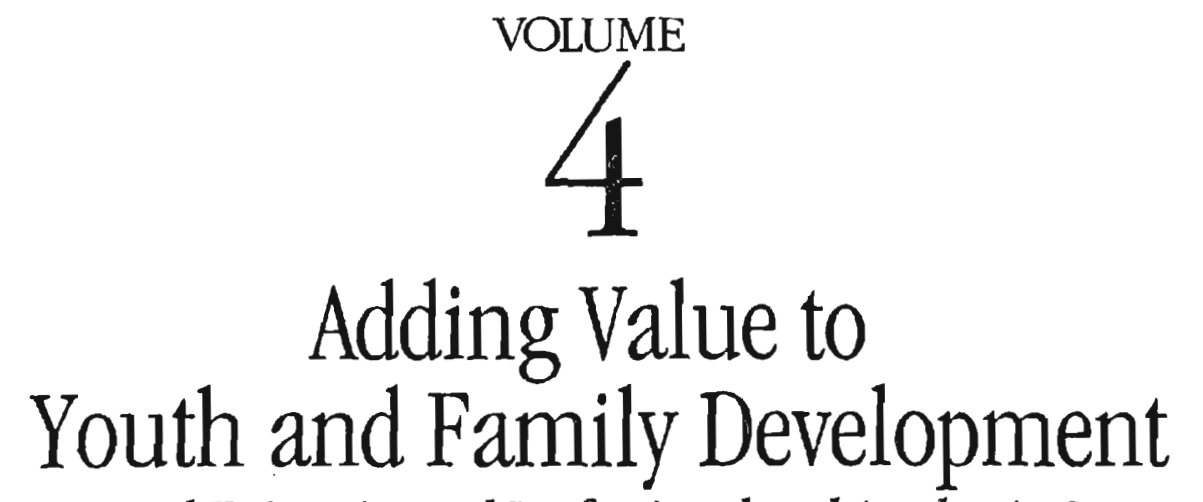

The Engaged University and Professional and Academic Outreach

Editors

Richard M. Lerner $\bullet$ Donald Wertlieb $\bullet$ Francine Jacobs Eliot-Pearson Department of Child Development, Tufts University 


\title{
Including Law in the Mix
}

\author{
The Role of Law, Lawyers, and \\ Legal Training in Child Advocacy
}

\author{
CATHERINe J. Ross
}

$\mathrm{T}$

This chapter describes trends in family law scholarship, training, and practice. An understanding of these trends will help child advocates from a variety of disciplines to appreciate the scope of the contribution that lawyers can make to child advocacy efforts. Advocates can then form more productive alliances with lawyers who share their concerns about the quality of life for children and families. The first section provides an overview of the scope of modern family law and the range of skills that lawyers bring to any enterprise. In the second section, the legal profession's burgeoning interest in using its collective talents to improve children's lives is placed in the context of broader intellectual trends in thinking about family issues and the values and structure of universities in the United States. The third section describes the current goals of legal education, discusses why law schools should offer interdisciplinary training to students who plan to work in family law, and summarizes some innovative multidisciplinary programs for training students in child and family law and advocacy.

\section{FAMILY LAW AND LAWYERING}

Until recently, family law focused principally on the orderly allocation and distribution of money, power, and property among the prosperous. Modern family law, in contrast, affects members of all social classes (Teitelbaum, 1996). Its purview concerns not only the creation and dissolution of family units but also the effort to define what constitutes a family when the adults have not chosen to enter into a legally sanctioned marriage, or when adults other than the parents informally assume child-rearing responsibilities, as in the case of grandparents or stepparents. Modern family law increasingly recognizes 
that its varied concerns may implicate competing policy goals. Such goals range from promoting social stability within family units and enforcing child support obligations to fostering personal autonomy for all family members and respect for cultural diversity among family units.

What constitutes "law" for purposes of this discussion? Too often, law students (and, perhaps, lay citizens) have a narrow notion of what constitutes "law," promoted in large part by the emphasis that lcgal education places on the "case method," in which students scrutinize appellate opinions (Blasi, 1995). They may conclude that lawyers are involved in only two endeavors: writing contracts and pursuing litigation. But the living law that influences everyday activities consists of statutes, administrative rules and regulations, decisions about how to interpret and enforce those laws and rules, as well as the interpretation of law that emerges when courts rule on specific cases and controversies-what lawyers call the "common law." Lawyers have a hand in making and enforcing all those components of the law. Collectively, the law helps to determine the poverty level, the availability of affordable housing for families, the quality of public education, and myriad other aspects of life that correlatc positively or negatively with healthy child development (American Bar Association [ABA], 1993). That makes social policy issues matters of concern to lawyers. When legal policies tolerate risk factors for children and families-factors such as poverty and homelessness or exposure to illegal drugs and weapons-lawyers also see the result within the justice system, illustrated by outcomes including foster care placement, delinquent activity, incarceration, and even premature violent death (ABA, 1993).

Coalitions to promote the interests of children and families need to reconceptualize how lawyers fit in. Child advocates too often fail even to contemplate seeking alliances with lawyers. One recent collection of "success stories" about university collaborations with communities "to promote the positive development of youth and families" contains less than a handful of references to involvement with either the law school or the community's lawyers and organized bar (Chibucos \& Lerner, 1999). Focus on Kids, a court-mandated parenting education program for divorcing parents in central Missouri, is described by its organizers as the result of "extensive collaboration with many community partners" (Chibucos \& Lerner, 1999). Its description stands out in mentioning lawyers. Yet even this program reported that it did not fully mine the potential participation of the legal community:

[W]e worked extensively with the court representatives, but, in hindsight, we could have worked more closely with lawyers in the two participating counties. We gave presentations on the program to representatives from the local bar associations, but it might have been better had we involved lawyers in the early planning. This might have resulted not only in an improved educational product, but also more support from the lawyers after the program started. (Fine et al., 1999, p. 252)

Support from lawyers might also have fostered a positive attitude among the divorcing parents whom the court ordered to attend. It is possible that this oversight stemmed in part from a popular misconception of lawyers as "hired guns" rather than counselors.

In the world of corporate law, widely regarded as the highest-status echelon of the profession (and certainly the best compensated), lawyers help their clients to anticipate and resolve potential legal problems before the problems escalate enough to bring the client to court (Higginbotham \& Ross, 1993). Lawyers advocate for the client before regulators, hypothesize about things that 
could go wrong and how to protect the client's interests or pursue an alternative route, advise on compliance and on how to reach goals while staying within the law. In short, attorneys are problem solvers (Blasi, 1995). All these skills can be harnessed to help children and families-as individuals and as constituencies-long before problems lead to juvenile or family court.

Lawyers can help families to obtain services they need, are entitled to, and have been denied, often preventing involvement with the formal justice system represented by the courts. One social work graduate student recalls that when she worked at a women's center with victims of domestic violence, she "continually found [herself] saying, 'You need to talk to a lawyer."' (Student No. 2, personal communication, Spring 2001, diary entry No. 5). She argues that the women involved in court hearings "needed an effective advocate" to tell their stories. Lawyers might also have helped her social work clients to obtain housing, collect child support, or obtain social services.

To be sure, it is crucial that lawyers represent children and families when they appear in court. Children are too frequently involved in legal proceedings without the benefit of legal counsel in cases concerning issues such as abuse or neglect, custody, visitation, and even delinquency, (when they have a constitutional right to counsel) (ABA, 1993; In re Gault, 1967). Improving the availability and quality of direct representation for children is a critical, though not sufficient, first step (ABA, 1993; Green \& Dohrn, 1996; Duquette, 1997). More is required.

What more can lawyers do? One analyst has answered the question, "what is it that lawyers do?" by "defining the central work of the lawyer as 'decision-maker, advisor, fact developer, advocate, friend, investigator, and organizer" (Menkel-Meadow, quoted in Blasi, 1995, p. 327). Practicing lawyers tend to describe their "ability to integrate factual and legal knowledge and to exercise good judgment in light of that integrated understanding" as the most important aspect of their job (Blasi, 1995, p. 326).

Lawyers draw on this range of skills in their role as advocates for children and families. The role of the lawyer embraces working through the legislative process, educating and battling with bureaucrats on behalf of individuals seeking benefits, helping clients learn how to advocate on their own behalf, and engaging in transactional practice (or deal making) that addresses problems such as the lack of adequate low-cost housing (Edelman, 1998).

In addition, whether or not practicing lawyers recognize the fact, much of their work affects the conditions of family life. For example, lawyers who represent the poor in noncriminal matters are frequently litigating cases that affect children's chances for positive development. The Legal Services Corporation, funded by the federal government "for the purpose of providing financial support for legal assistance in noncriminal proceedings or matters to persons financially unable to afford legal assistance" (Legal Services Corporation v. Velazquez, 2001, p. 1046), finds that its caseload is dominated by matters that concern the quality of family life. The vast majority of legal services cases involve issues defined as family law cases (including such issues as domestic violence, child support, and representation related to foster care or other involvement with the child welfare system); housing cases, in which families with children seek to hold on to their apartments or to obtain habitable conditions; or collection of government benefits, including payments for children with disabilities (Legal Services Corporation, 2001). Similarly, lawyers who work on environmental issues may be seen as working for children, since environmental hazards disproportionately affect poor children, especially those who are members of minority groups (ABA, 1993, p. 40). 


\section{TRENDS IN PRACTICE AND PROFESSIONALISM}

This section identifies a convergence of trends in three professional settings: the academy generally, the field of child development, and the law. In each instance, social reform has been seen as a key to improving the lives of children, and, conversely, children have been seen as the key to social reform. Leading theorists in each field have urged collaboration among the professional disciplines to better serve the holistic needs of children and their families.

\section{Reformist Visions of the Academy}

Too often, critics assert, basic research has become so dominant a priority in universities that it has pushed aside teaching, service, practice, and application (Boyer, 1990, 1994). This has led, they argue, to a normative narrowing of what it means to be a scholar within the U.S. academy over the last forty years. (Others have criticized this trend as it has manifested itself in the legal academy; see Edwards, 1992, and Woodhouse, 1993). Ernest Boyer criticized the broader trend in a seminal report issued by the Carnegie Foundation for the Advancement of Teaching on the state of scholarship in U.S. universities in 1990. He identified four types of scholarship that he argues should be equally valued:

1. The scholarship of discovery-that is, knowledge for its own sake, or what is commonly known in some fields as theoretical research

2. The scholarship of teaching, which assumes that the scholar's discovery becomes meaningful when transmitted to others and understood by them in a process which also extends the scholar's understanding
3. The scholarship of integration, which includes making connections across disciplines, placing knowledge in a broader context, and summarizing existing research for a broader audience

4. The scholarship of application, which asks how academic knowledge can be helpful to individuals, families and communities. (Boyer, 1990, 1994)

Some of its proponents refer to the combination of the four approaches as "outreach scholarship" (Lerner \& Simon, 1998).

Boyer went further. He expressly linked the revitalized university he envisioned to service to children. Summarizing his report in the Chronicle of Higher Education, Boyer exhorted readers to "consider the condition of our children." Rhetorically, Boyer asked,

Can colleges and universities honestly conclude that the crises confronting America's children are someone else's problem?... Do colleges really believe they can ignore the social pathologies that surround schools and erode the educational foundations of our nation?" (Boyer, 1994, p. 48)

In another field, economist Paul Krugman (1998), an economics professor and author of a regular op-ed column in the New York Times, explains in similar terms his decision to devote some of his energies to making economics penetrable:

For most of my professional life I did what most academics do: I taught my classes, wrote papers for professional journals, and in general talked mainly with other academics. As far as I was concerned, getting at the truth and convincing a select audience of cognoscenti that I was right was all that mattered; it was somebody else's job to communicate the truth to the world at large. (p. 9)

Then, Krugman reports, he realized, "I cannot count on somebody else to make the case 
for the kind of economics I believe in; if I want that case made, I'll have to do it myself" (p. 9).

\section{Transforming Our Understanding of Children, Families, and Social Policy}

A quarter of a century ago, a few social scientists began to promote a holistic approach to healthy child development and family life. Like Krugman, they realized that if they wanted their case made well, they would have to do it themselves. They applied their theories on several fronts: scholarship, public policy, and training younger generations of scholars and child advocates, anticipating the theories of outreach scholarship and providing exemplars of it.

Urie Bronfenbrenner (1979), for example, developed a theoretical paradigm to study human development, which he labeled "the ecology of human development." He argued that individuals and families do not exist in isolation. Rather, like other organisms, humans exist in a context that can either promote or inhibit healthy development. According to Bronfenbrenner, family life and the development of children can be strengthened if we understand and nourish the positive interactions among individuals, institutions and the broader social environment, while identifying and addressing the causes of negative influences (as cited in Babb, 1997).

In 1973, Edward Zigler, then serving as the first director of the federal Office of Child Development, exhorted Congress to analyze each policy proposal's impact on family life when assessing its costs and benefits (Steiner, 1981, p. 28). After Zigler left government to return to Yale University, he founded the Bush Center in Child Development and Social Policy to bring current research knowledge about child development into discussions about policy, with the goal of improving the lives of U.S. children and families. Since 1978, the center's interdisciplinary faculty has trained predoctoral and postdoctoral students and mid-career fellows from a variety of fields about how to conduct research and evaluate policy that affects children, as well as how to apply their academic knowledge in the world of policy. The center also devotes energy to educating the public and policymakers about the developmental needs of children and analyzes policies affecting children and families. Scholars at the center conduct policy-related research and mount national initiatives to solve identified problems such as the unmet need for highquality, affordable day care. Today, nearly 400 fellows-primarily psychologists-have received training at the Bush Center. Among the graduates are a number of lawyers, including some, like me, who pursued their legal training after leaving the Bush Center (Bush Center in Child Development and Social Policy, 2000).

\section{Responses in the Legal Profession}

During the last decade, the legal profession has also paid increasing attention to the broad needs of children and families. In 1993, the American Bar Association issued America's Children at Risk: A National Agenda for Legal Action. The report was premised on the notion that lawyers "can no longer confine [their] vision to a narrow focus on 'law,' but must look for ways in which legal changes can redress broad social problems" (Higginbotham \& Ross, 1993, p. vi). The report relied on numerous studies from many disciplines in addressing the broad legal reforms in areas such as income distribution, housing, education, and health care that seem necessary to fulfill children's essential needs. The report recommended many initiatives, including collaboration among the professions on behalf of children 
before the children become involved with the justice system. It also recommended the development of new curricula to train law students to serve the needs of child clients and a variety of projects for individual lawyers and the organized bar to pursue on behalf of children. Immediately after the publication of America's Children at Risk, the ABA established the Steering Committee on the Unmet Legal Needs of Children to coordinate the response of lawyers and the organized bar to the problems that the report identified. I had the honor of serving that committee, first as vice chair and then as chair, from 1993 to 1998.

In response to America's Children at Risk, the organized bar has encouraged lawyers to serve children and families through pro bono ${ }^{1}$ legal work and other activities (Duquette, 1997). For example, the ABA's Children's SSI Project marshaled pro bono assistance that helped to restore disability benefits to thousands of poor children around the country. The SSI Project developed a training manual for use by state and local bar associations and recruited approximately 5,000 attorneys to volunteer their services (Singleton, 1998). Local bar associations in large cities, including Philadelphia and San Diego, issued their own reports on children's legal needs in their communities. The ABA's Young Lawyers Division made children a priority. The Young Lawyers (those who are under the age of 35 or have been in practice for less than five years) and their state and local bar affiliates carried out enough projects responsive to children's needs to fill a phone book in a large urban center, including providing special children's waiting rooms in courthouses all over the country. Many law firms also focused their pro bono, philanthropic, and nonlegal volunteer work on children's projects. The ABA itself reaffirmed its commitment to children by issuing an updated report entitled America's Children: Still at Risk in 2001.
In addition to directing its own attention to the needs of children and families, the legal profession has incrcasingly recognized the potential of cooperating with other professions when attempting to resolve family issues such as divorce, child custody, and abuse or neglect. The trend toward increasing acknowledgement of what other disciplines have to offer is particularly important in the reorganization of courts that handle cases involving family issues. Traditionally, the state courts that handle almost all family matters are fragmented, overburdened, and inefficient. Too often, one judge hears a matrimonial property dispute, another decides child custody issues, and yet a third hears a matter involving substance abuse or domestic violence in the same family. In response to these problems, there has been a groundswell of interest in unified family courts. Unified family courts take many forms but generally have four common elements: (a) comprehensive jurisdiction, so that all matters involving the same family unit are heard by one judge; (b) efficient administration, supporting the concept of "one family, one team"; (c) multidisciplinary training for all court personnel, from intake staff to judges; and (d) the ability to ensure that farnily members receive the services they need (Ross, 1998, 1999).

An emphasis on multidisciplinary training and a focus on delivery of services in unified family courts can be expected to promote cooperative interactions between lawyers and judges on the one hand and social workers, psychologists, and other professionals who serve families on the other. These developments are both reinforced by and help give rise to the notion of practicing holistic family law. "Holistic lawyering," one commentator explains, requires lawyers

to envision a positive end result for the client, that is more than prevailing on a legal issue, and to use their legal skills so the client reaches this result.... Holistic 
lawyering does not require attorneys to become experts in new field of law." (Zotter, 2000, p. 86)

Nor are holistic lawyers expected to become experts in related nonlegal fields. They are best prepared for holistic lawyering when they learn enough about other specialties to frame the right questions and know how to interpret the answers. It is well-known in legal practice that the answer frequently depends on the way the question is framed. A lawyer whose client is a victim of domestic violence, for example, needs to know that it would be helpful to ask questions about housing, employment, entitlement to benefits, and whether child protection issues also exist. Then, the lawyer must know where to turn to find resources in response to the answers generated. The victim and her children all stand to benefit from the holistic intervention (Zotter, 2000).

In 1996, the ABA adopted Standards of Practice for Lawyers Who Represent Children in Abuse and Neglect Cases. Among other things, the standards call for educational training on the role of a child's attorney that includes the following:

1. Focus on child development, needs, and abilities

2. Information on the multidisciplinary input required in child-related cases, including information on local experts who can provide consultation and testimony on the reasonableness and appropriateness of efforts to safely maintain the child in his or her home

3. Information concerning family dynamics and dysfunction including substance abuse, and the use of kinship care

4. Information on accessible child welfare, family preservation, medical, educational, and mental health resources for child clients and their families, including placement, evaluation/diagnostic, and treatment services; the structure of agencies providing such services as well as provisions and constraints related to agency payment for services. (ABA, 1995)

Lawyers who represent children in contexts other than abuse and neglect, as well as those who represent parents, benefit from similar training. In light of the requirements in many jurisdictions that licensed attorneys complete a certain number of hours of Continuing Legal Education on a regular basis, professionals with relevant specialized knowledge (such as developmental psychologists and social workers) should find a ready audience if they collaborate with bar associations or courts to set up training programs.

These developments have contributed to a growing legal commentary on working collaboratively with other professions (Babb, 1997; Meier, 1993; Stolle, 1996). At the same time, initiatives have developed to introduce interdisciplinary training to the family law curriculum in law schools, some of which are described in the next section.

\section{TRENDS IN LEGAL EDUCATTON}

The general trends in universities, as identified by Boyer (1990), apply with at least equal force to the nation's law schools. The more prestigious the law school, the more highly its faculty is likely to value the purity of the scholarship of discovery, with rapidly decreasing interest in teaching, integration, and application (Edwards, 1992). The chief judge of the prestigious federal court of appeals for the District of Columbia has expressed concern that the "elite" law schools increasingly favor "pure theory" at the expense of practical scholarship, teaching future practitioners, and responding to "pressing social problems." Judge Edwards emphasized that, although "a great law school can never be antitheoretical," legal 
academics, like practicing lawyers, have an "obligation to serve the system of justice" (Edwards, pp. 38-39). The problem may be one of balance, for both the institution and the individual professor. Each professor may not have the inclination to serve equally on all four fronts, and individuals may find that their own balance among the types of scholarship shifts over time. Obstacles to contributions in areas other than "the scholarship of discovery," in Boyer's terms, remain potent. The academy finds it hard to measure, much less reward, achievements outside the realm of published scholarship. Despite the structural disincentives, however, individual scholars may find that their endeavors in the four realms are mutually reinforcing, particularly in fields such as the law concerning children and families.

This section summarizes the aspirational goals of professional training in law and discusses the particular need for interdisciplinary training of lawyers who plan to serve children and families in areas such as differing uses of language and professional ethics. It then describes a number of clinical and interdisciplinary programs in law schools that may serve as models for further innovation.

\section{The Goals of Legal Education}

An influential report issued in 1992 known as the "MacCrate Report" called on law schools to reexamine the successes and limitations of legal education (ABA Section of Legal Education, 1992). The report concluded that, despite rumors to the contrary, no chasm separated the legal academy from the legal profession. To help smooth the difficult journey from school to practice and professionalism, the MacCrate Report offered a hortatory statement of 10 skills and four values central to the legal profession, as a guidepost to improving professional development.
The fundamental lawyering skills identified include: (a) problem solving; (b) legal analysis and reasoning; (c) legal research; (d) factual investigation; (e) communication; (f) counseling; (g) negotiation; (h) litigation and dispute resolution techniques; (i) organization and management of legal work; and (j) recognizing and resolving ethical dilemmas (ABA Section, 1992). The MacCrate Report also identified four fundamental values that elevate the practice of law to a profession (ABA Section, 1992, p, 108). These include the lawyers duties to

1. provide competent representation;

2. strive to promote justice, faimess, and morality

3. improving the profession; and

4. engage in professional se]f-development. (ABA. Section, 1992)

The MacCrate Report exhorted law schools to nurture these skills and values in both traditional classrooms and clinical training. All the enumerated skills and values would be nourished in either a traditional law school clinic or interprofessional project serving children and families.

\section{The Need for and Scope of Interdisciplinary Training}

The study of the family, in law as in many other disciplines, has proven a fertile ground for interdisciplinary collaboration. If lawyers who represent or advocate on behalf of children and families will need to work with professionals from other disciplines, how can law schools hetter prepare them to do so? The ability to function in a cross-disciplinary world does not require that lawyers attain the knowledge that training in another discipline provides. Interdisciplinary legal education strives to accomplish two related goals: (a) to familiarize the lawyer with the vocabulary 
and scope of other professions' competencies so that lawyers can be better informed about where, when, and how to seek collaboration; and (b) to help lawyers learn how to communicate and work with their counterparts in other fields in order to serve their clients more effectively (Peters, 1997).

For example, great potential for misunderstanding arises when members of different professions discuss who the client is and what their respective codes of ethics require in terms of confidentiality. Differences in language are based on entrenched assumptions. "One colleague says 'client,' one says 'patient,' one says 'student'" (Brabeck et al., 1998 , p. 340)-each referring to the same person. Presented with a case study, the educator who refers to the troubled teen as a student and the psychologist who calls her a patient may both be appalled when they ask the lawyer's impression. As I have on occasion, the lawyer may respond with the query: "Who is my client?" If the client is the teenager, the lawyer may have one set of obligations, whereas if the client is the teenager's parent or the school, the lawyer may have quite different professional obligations.

Even where different professions use the same term, the term may mean something quite different depending on who uses it. Consider the term "client," an essential building block on which everything else rests. The code of ethics for the social work profession states that the term "clients" is "used inclusively to refer to individuals, families, groups, organizations, and communities" (National Association of Social Workers [NASW], 1999). A social worker or other mental health professional may be able to advise all members of a family simultaneously, even when their expressed individual interests vary (St. Joan, 2001). In stark contrast, the awyer's use of the term "client" is exclusive. The lawyer's ethical code makes it clear that 1 lawyer shall not ordinarily represent a client if the representation will or has the potential to adversely affect another client, past or present (ABA, 2001b, Rules $1.7 \&$ 1.9). The definition of "adversely affect" is broad, because the lawyer has an obligation to "represent a client zealously within the bounds of the law" (Morgan \& Rotunda, 2001, Canon 7, DR 7-101).

These professional distinctions come to the fore when issues arise concerning confidentiality. According to the social work code, the "general expectation that social workers will keep information confidential does not apply when disclosure is necessary to prevent serious, foreseeable, and imminent harm to a client or other identifiable person" (NASW, 1999 1.07[c]). Social workers, teachers, doctors, and many others are mandated reporters of child abuse in most jurisdictions. Lawyers are not. Lawyers may not disclose confidential information about their clients-whatever the source-without the client's consent unless very narrow exceptions apply, such as the client's intent to commit a future crime (ABA, 1980, DR 4-101). Under these standards, a lawyer may not disclose child abuse reported to her by a client who is the abused child without the child's consent; similarly, child abuse reported by a parent who is the client cannot be disclosed without consent, whether or not that parent (the client) is the abuser. The obligation to preserve confidentiality stems from the premise that, in legal practice, the client directs the representation. In other professional relationships, the client frequently does not maintain the control. This definition of the lawyer's obligation may be particularly difficult for nonlawyers to understand and should be a particular focus of interdisciplinary training (St. Joan, 2001).

In an ideal world, rich in resources, interdisciplinary training would be offered as a part of professional education, before students become entrenched in the peculiarities of 
their chosen fields, and would continue even after they become seasoned professionals. The final section of this chapter describes some innovative law school programs that offer interdisciplinary training.

\section{Model Law School Projects}

The starting point for training law students is of course the lecture courses and seminars offered at many law schools on families, children, and the law. A number of law schools also offer clinical programs in which students represent children or their families. Recently, a growing number of law schools have begun to develop innovative programs to prepare students for collaboration with people trained in other disciplines in working on matters involving children and families. The remainder of this chapter describes some of those collaborative programs as well as some more traditional law clinics that have interdisciplinary aspects.

I have made no effort to catalogue all interdisciplinary programs concerning children at law schools, in part because of the fluidity and grant dependency of many of the programs. Rather, I have selected for discussion programs that represent interesting departures and provide a variety of promising models. Collectively, the programs provide opportunities for all four modes of scholarship advocated by Boyer and described in the previous section.

\section{Law Clinics Plus}

The first group of projects may be loosely referred to as "law clinics plus." Generally speaking, these are clinics on the traditional model, developed within the law school, perhaps with some participation by an individual representing another profession such as mental health, training primarily or only law students, and perhaps engaging in systemic reform or providing some services to clients beyond traditional clinical legal representation. This group includes programs at the University of Michigan, Ohio State University, Loyola University Chicago, and George Washington University.

\section{Child Advocacy Law Clinic at the} University of Michigan. One of the oldest existing clinics devoted to the needs of children and families, Child Advocacy Law Clinic at the University of Michigan, is devoted to cases involving child abuse and neglect (Duquette, 1997). One distinguishing feature of the clinic is that students take on three distinct types of representation: as attorney for the child, as attorney for the parents, and as attorney for the child welfare agency. A student avoids conflicts of interest because the clinic accepts cases from different counties in Michigan, so that the same student does not represent, for example, any parents in the same county in which that student represents the state agency. The clinical training provided to law students involves interdisciplinary supcrvision by faculty members from law and at least one faculty member from child psychiatry, social work, psychology, or pediatrics, depending on the year and the available funding. Students participate in multidisciplinary group conferences. The clinic emphasizes the importance of building a productive "relationship between the lawyer and other child welfare professionals" (Duquette, 1997, p. 8).

Beyond its work on individual cases, the clinic has engaged in law reform projects including impact litigation, such as an action against a county juvenile court for neglecting the children under its jurisdiction (Virtue $v$. Wayne County Juvenile Court, 1979). Its students have helped to draft statutes for the state legislature and prepared legislative testimony.

The clinic's activities are complemented by several other opportunities within the law 
school. An interdisciplinary seminar on child abuse and neglect uses actual cases and considers how different disciplines would resolve the complex issues they raise (Scarnecchia, 1997). Participating faculty come from law, social work, and psychology; all of them are actively engaged in practice involving child welfare issues. In addition, a Child Welfare Law Resource Center founded in the late 1990 s draws on the expertise gained through the child advocacy clinic. It provides resources and consultation to practicing lawyers and judges in response to requests, offers training to the bench and bar, develops interdisciplinary resource materials, and publishes a quarterly entitled the Michigan Child Welfare Law Journal.

Justice for Children Project at the Obio State University College of Law. The Justice for Children Project at Ohio State, which began full-time operations in 1998, is a joint venture of the law faculty and the university's multidisciplinary Center for Law, Policy, and Social Science. ${ }^{2}$ The project has two synergistic foci: direct representation of children in a children's rights law clinic and research and initiatives leading to law reform. As its director explains, the project supports scholarship "that provides philosophical support for the work of children's rights advocates by building bridges between theory and practice and by considering and integrating the findings of other disciplines" (K. H. Federle, personal communication, July 2001). In addition to publishing scholarly articles and sponsoring nationally recognized symposia, the project applies its research through activities such as filing amicus curiae ("friend of the court") briefs in appellate cases and working with the state legislature.

Civitas Child Law Center at Loyola University Chicago School of Law. Loyola
University Chicago School of Law goes beyond isolated curricular offerings. It has created three multidisciplinary tracks for training child advocates aimed at students from different backgrounds (Myers, 1993). ${ }^{3}$ The first course of study, initiated in 1993, is a discrete track for law students enrolled in the regular doctor of jurisprudence (JD) program (the first-level law program). This program trains law students who plan to become advocates for neglected and abused children and offers need-based scholarships to students who make a commitment to represent children after graduation. Students enrolled in the program take a four-course sequence on children and the law during their second and third years of law school, including an advanced interdisciplinary seminar and a specialized trial practice course on courtroom advocacy for children; these courses are also open to other law students. In addition, the law students pursue internships devoted to child advocacy during the first and second summers of law school.

A second program aimed at the legal profession offers the postgraduate master of laws (LLM) degree to attorneys who already hold law degrees (usually from other law schools). Candidates may specialize in either family law or child advocacy. Those enrolled in the postgraduate child advocacy track take the same academic courses provided for the JD candidates in children and the law, as well as participating in a child advocacy clinic (also open to JD candidates) that represents children in delinquency, child protection, and other proceedings.

Perhaps the most unusual aspect of the Civitas program is the third track, which offers a master of jurisprudence (MJ) degree in child law to professionals with degrees in other fields (such as medicine, mental health, social services, and education) who "seek a better understanding of the law and its impact on children and families" (Graduate 
Child Law Programs, n.d.). This course of study includes a targeted introduction to legal systems for nonlawyers, as well as the core curricula offered to the JD and post-JD students, including the child law clinic. Participants may also elect courses in other professional schools within the university.

\section{Domestic Violence Clinics at the George} Washington University Law School. George Washington offers law students two clinical experiences focused on domestic violence. The Domestic Violence Litigation Clinic (DVLI) founded in the early 1990s (Meier, 1993) ${ }^{4}$ and the Domestic Violence Emergency Department Clinic founded in 1999 (Jacobson, 2001). The approach of both clinics is interdisciplinary.

DVLI established by a member of the law school clinical faculty with the help of a clinical psychologist on the staff of the university's medical school. Although the clinical psychologist no longer coteaches the course (she accepted a job at another university), the course continues to rrain students in the psychosocial dynamics of battering. Today, the clinic includes the services of a licensed clinical social worker who helps to teach the course and also counsels clients. Students offer holistic representation to their clients, who are primarily battered women and their children. In addition to seeking and enforcing protective orders, students work to protect the children of victims by arranging safe visitation conditions or moving to bar visits with the abuser altogether. They also help with diverse needs, including housing and medical care. This work typifies many domestic violence law clinics, as described in Merryman (1993) and St. Joan (2001). Faculty and students at George Washington have also engaged in law reform projects, including developing resource and referral lists and assisting defense attorncys in cases involving battered women. Their analysis of what goes wrong when victims of domestic violence present at hospital emergency rooms led directly to the founding of the second clinic.

The Domestic Violence Emergency Department Clinic is a unique collaboration of the law school and the medical school, under the supervision of faculty from both the law school and social work school. It is one of the first programs in the country to train law students to provide advocacy for victims of battering in the emergency room. The structure is simple. Students who have received interdisciplinary training take turns being on call when the emergency room staff identify victims of abuse. Law student interventions include support, information about legal responses and remedies (such as civil protection orders and the availability of victim compensation funds) as well as risk assessment and safety planning. Students engage in immediate advocacy activities (such as locating shelter space) and other social services (such as drug rehabilitation or other counseling programs). If the patient consents, the same student can provide follow-up advocacy after the patient leaves the emergency room, including legal research, helping the victim find legal counsel, or accompanying the victim to court.

Medical settings offer a rich opportunity for outreach and intervention, connecting clients at their most vulnerable with legal and other services in a setting where they feel safe. Law students in this clinic hold some interdisciplinary seminar sessions in common with the students in the DVAP clinic and also have the option of auditing a medical school class on domestic violence and medicine. The crossdisciplinary enrichment flows both ways; medical staff who have worked with the student advocates have developed enhanced sensitivity to domestic violence and have increasingly started to inquire about domestic violence during their own interviews with patients. 


\section{Cooperative Ventures}

I arbitrarily placed the George Washington Domestic Violence Emergency Department Clinic in the "law clinic plus" category because the law school holds primary responsibility for it, and only law students enroll. It can also be viewed as representing a transition to the second category of programs, which I have labeled "cooperative venturcs." Such programs are conceived and initiated by faculty from more than one part of the university and are designed to train students from law along with students from other disciplines while serving a needy population. These programs include the Center for Children's Policy, Practice, and Research at the University of Pennsylvania and activities of the Center for Children's Advocacy located at the University of Connecticut School of Law.

Center for Children's Policy, Practice, and Research at the University of Pennsylvania. The Center for Children's Policy, Practice, and Research (CCPPR) was founded in 1999 as a joint project of the Schools of Law, Medicine, and Social Work, with participation from faculty members in nursing as well as the arts and sciences (Cowan, Steinberg, \& Woodhouse, 2002). The CCPPR-an acronym intentionally alluding to "a double dose of CPR (cardiopulmonary resuscitation)" for the child welfare system-aims to mobilize the resources of all of the disciplines engaged in issues concerning children across the campus to "seek innovative solutions for the crises facing America's children" (Center for Children's Advocacy, n.d.). The interdisciplinary setting is key to all of CCPPR's activities, which give equal weight to practice, policy, and research. ${ }^{5}$

The center's multidisciplinary approach is applied in five streams, or "teams" as CCPPR designates them, which respond to a variety of matters ranging from one child's case to policy formulation on the state and national levels. First, "clinical teams," comprised of social workers, psychologists, nurses, physicians, and lawyers provide clinical assessments and expert restimony in legal proceedings at the request of judges or of lawyers representing children. The lawyer's role in the team differs significantly from the projects described elsewhere in this chapter, in that the lawyer's assignment is to help the other team members to understand the legal issues and what kinds of information will weigh in legal decision making-not to assume representation of the child or any other party. Graduate, students in all the disciplines-including law-participate in the teams under faculty direction. Second, the "research team," composed of scholars investigating child welfare and juvenile justice issues, pursues theoretical and applied research projects.

Third, a "technical assistance/training team" is available for consultations with agencies that seek to improve or evaluate their own programs. Examples of such consultation include assessment of compliance with consent decrees ensuring children's access to child protection, mental health, and special education services; interdisciplinary training is also provided for district attorneys in dealing with sexual abuse cases involving children and for family court judges.

A fourth team emphasizes "law and policy" by activities such as providing legislative testimony to Congress and to state legislatures around the country, filing amicus curiae briefs, and developing a national network of advocates for children. A fifth team, the "technology and dissemination team," disseminates the center's research findings, position papers, model laws, and briefs. ${ }^{6}$ Students have opportunities to participate in the work of all five approaches. The five activities are synergistic for faculty and students alike. For example, a recent amicus 
curiac brief to the United States Supreme Court drew on the center's clinical records and social science as well as legal research; it also benefited from consultations with the emerging national network of child advocates.

Center for Children's Advocacy at the University of Connecticut School of Law. Unlike the other programs described here, the Center for Children's Advocacy is a private, nonprofit corporation rather than a university-sponsored project. The center is housed at the University of Connecticut Law School, from which it receives valuable in-kind services. Founded in 1997, the center has two equally important missions: "to provide holistic services to children in their communities and to improve the quality of legal representation of children" (Center for Children's Advocacy, n.d.). It pursues these twin missions through a variety of activities including individual legal representation; impact litigation; policy advocacy; and interdisciplinary collaborative efforts with, among others, the local public schools; the juvenile defender's office; and the law, medical, and social work schools at the University of Connecticut.' Each semester, the center offers internship opportunities to law students, some of whom are also candidates for joint degrees in social work. The center also offers training and support to practicing lawyers who volunteer to provide pro bono representation to children.

The Center for Children's Advocacy was instrumental in forging a partnership among the university's schools of law, medicine, and social work dedicated to an interdisciplinary approach to children's medical and mental health issues. An interdisciplinary team consisting of faculty and students from all three schools hold monthly conferences. The students collaborate on individual cases under faculty supervision from all three disciplines.

One of the center's unique collaborations is the Medical-Legal Partnership Project, which aims to improve the health and welfare of low-income children through "proactive legal assistance provided in a health care setting" (Sicklick, 2001). The project began in the spring of 2000 when health providers at the Connecticut Children's Medical Center realized that many of their patients had health care needs that could best be met through legal assistance-needs such as adequate housing, nutrition, social services and special education (Goldberg, 2001). The medical center and the Center for Children's Advocacy began a joint project in which the hospital refers patients for individual legal representation. The Center for Child Advocacy also trains health care providers on laws related to children's health care needs, including confidentiality in adolescent health care, and it advocates for children and families at large on such issues as Medicaid coverage of nutritional supplements for chronically ill children. Its range of projects illustrates the synergistic process typical of many interdisciplinary programs.

Similar initiatives are in place or in progress at other universities around the country. Each program embodies Boyer's vision of outreach scholarship. Law school "clinics plus" and cooperative ventures focused on children are designed to promote opportunities for (a) theoretical research, (b) meaningful teaching, (c) integration of knowledge across disciplines and to audiences outside the university, and (d) direct service to individuals, families, and communities. The balance among these four goals may vary from program to program, or even within the same program at different junctures in the program's development.

A broad vision of the lawyer's role permeates creative law school programs that offer interdisciplinary training, whether the programs are law clinics plus or cooperative ventures with other departments and schools. That vision incorporates the professional 
obligation-which permeates the American Bar Association Standards for Attorneys in Child Abuse and Neglect Cases-not merely to represent children in court proceedings, but also to assist them through a profoundly traumatic process and advocate for dispositions, educational and other placements, and services that successfully address their needs. (Goldberg, 2001, p. A20)

That professional obligation motivates all of the programs described here. The growing number of interdisciplinary programs that train law students to work with members of other profcssions in the service of children, and the increasing sophistication of existing programs, holds great promise for transforming how legal institutions and the people who staff them think about and respond to children's problems.

\section{CONCLUSIONS}

Increasingly, law has joined other helping professions in recognizing the complex interactions that affect child development and the need for both individual interventions and structural reform on behalf of individual children and families. Because the law is implicated in virtually every aspect of modern life, and because lawyers possess so many critical skills for effecting change, lawyers have the potential to make important contributions to child advocacy coalitions. The generation of lawyers being trained today, many of whom are beneficiaries of creative interdisciplinary training, will be even better prepared to collaborate with other professionals on behalf of children — and many of them will be actively seeking opportunities to do so.

1. The Latin phrase, pro bono publico, which means "for the good of the public," is the term lawyers use to identify uncompensated legal work that benefits society. Pro bono work includes representation of the poor, impact litigation to address systematic injustice, or providing legal counsel to nonprofit organizations that serve the community.

2. The Center for Law, Policy, and Social Science was formerly known as the Center for Socio-Legal Studies. The description of the Justice for Children Project is based on information provided by its director, Katherinc Hunt Fedcrlc. For general inquiries, information is available online (retrieved Junc 13, 2002, from www.law.ohio-state.edu/JFC).

3. Discussion based on application materials and course descriptions available from Professor Diane Geraghty, Loyola University School of Law.

4. My summary of the clinic's current program is based on personal conversations with Professor Meier and on the course description (retrieved June 13, 2002, from www.law.gwu.edu/acad/clinics.asp). Additional information may be obtained from the Jacob Burns Community Legal Clinics at the George Washington University Law School. Although I teach conventional classroom courses and have not taught in this program, many of my students in family law courses have benefited from their participation in the clinics.

5. Despite its short existence, the CCPPR approach is already being replicated. Professor Barbara Bennett Woodhouse, a founding CCPPR codirector from the law school, recently accepted a chair at the University of Florida, which has asked her to build a similar project there. In the fall of 2001 , I was a visiting associate professor at the University of Pennsylvania Law School and served as visiting senior research scholar at CCPPR for the 2001-2002 academic year. 
6. Additional information is available at the CCPPR Web site (www.law.upenn.edu/ccppr/).

7. Information on the full range of the center"s educational activities and service programs is available at its Web site (www.kidscounsel.org/).

\section{REFERENCES}

Amcrican Bar Association (1993). America's children at risk: A national agenda for legal action. Report of the Presidential Working Group on the Unmet Legal Needs of Children and Their Families. Chicago: Author:

American Bar Association: (1994). Policy on unified family courts. Family Law Quarterly, 32, 1-2.

American Bar Association. (1995). Standards of practice for lawyers who represent children in abuse and neglect cases. Family Law Quarterly, 29, 375-405.

American Bar Association (2001a). America's children: Still at risk. Chicago: Author. American Bar Association. (2001b). Model rules of professional conduct. Chicago: Author.

American Bar Association, Section of Legal Education and Admissions to the Bar. (1992). Legal Education and Professional Development-An Educational Continurim, Report of the Task Force on Law Schools and the Profession: Narrowing the Gap (MacCrate Report). Chicago: Author.

Babb, B. A. (1997). An interdisciplinary approach to family law jurisprudence: Application of an ecological and therapeutic perspective. Indiana Law Journal, 72, 775-808.

Blasi, G. L. (1995). What lawyers know: Lawyering expertise, cognitive science and the functions of theory. Journal of Legal Education, 45, 313-397.

Boyer, E. (1990). Scholarship reconsidered: Priorities of the professoriate. Princeton, NJ: Carnegie Foundation for the Advancement of Teaching.

Boyer, E. (1994, March 9). Creating the new American college. Chronicle of Higher Education, p. A48.

Brabeck, M., Cawthorne, J., Cochran-Smith, M., Gaspard, N., Green, C. H., Kenny, M., Krawczyk, R., et al. (1998). Changing the culture of the university to engage in outreach scholarship. In R. M. Lerner \& L. A. K. Simon (Eds.), University-community collaborations for the twenty-first century: Outreach scholarship for youth and families (pp. 337-364). New York: Garland.

Bronfenbrenner, U. (1979). The ecology of human development. Cambridge, MA: Harvard University Press.

Bush Center in Child Development and Social Policy. (2000, November 30). Annual progress report. (Available from the Bush Center in Child Development and Social Policy, Yale University, 310 Prospect Street, New Haven, CT 06511)

Center for Children's Advocacy, Program Profiles. (n.d.). Unpublished pamphlet, University of Connecticut School of Law, Hartford. (Available from Martha Stone, Center for Children's Advocacy, University of Connecticut School of Law, 65 Elizabeth Street, Hartford, CT 06105)

Chibucos, T., \& Lerner, R. M. (Eds.). (1999). Serving children and families through community-university partnerships: Success stories. Norwell, MA: Kluwer.

Cowan, A. B., Steinberg, A., \& Woodhouse, B. B. (2002). Child-centered, vertically structured and interdisciplinary: An integrative approach to children's policy, practice and research. Family Court Review, 40, 116-134.

Duquette, D. N. (1997). Developing a child advocacy law clinic: A law school clinical education opportunity, University of Michigan Journal of Law Reform, 31, 1-32. 
Edelman, P. (1998). Responding to the wake-up call: A new agenda for poverty lawyers. Review of Law and Social Change, 24, 547- 561.

Edwards, H. T. (1992). The growing disjunction between legal education and the legal profession. Michigan Law Review, 91, 34-78.

Fine, M. A., Coleman, M., Gable, S., Ganong, L., Ipsa, J., Morrison, J., Thornburg, K. (1999). Research-based parenting education for divorcing parents: A university-community collaboration. In T. R. Chibucos \& R. M. Lerner (Eds.), Serving children and families through community-university partnerships: Success stories (pp. 249-256). Norwell, MA: Kluwer.

Goldberg, C. (2001, May 16). Boston Medical Center turns to lawyers for a cure. New York Times, pp. A20.

Graduate Child Law Programs, Master of Jurisprudence (MJ in Child Law). (n.d.). Unpublished pamphlet, Loyola University Chicago.

Green, B. A., \& Dohrn, B. (1996). Foreword: Children and the ethical practice of law, Fordham Law Review, 64, 1281-1298.

Higginbotham, A. L., \& Ross, C. J. (1993). Introduction. In American Bar Association, America's children at risk: A national agenda for legal action. Chicago: American Bar Association.

In re Gault, 387 U.S. 1 (1967).

Jacobson, W. (2001). The George Washington University DomesticVuiolence Emergency Cepartment Clinic: A new medicalllegal collaboration on behalf of battered women. Unpublished manuscript.

Krugman, P. (1998). The accidental theorist: And other dispatches from the dismal science. New York: Norton.

Legal Services Corporation v. Velazquez, 121 S. Ct. 1043 (2001).

Legal Services Corporation. (2001). Press kit: Fact sheet. Retrieved June 13, 2002, from http://www.lsc.gov/pressr/pr_fact.htm

Lerner, R. M., \& Simon, L. A. K. (Eds.). (1998). University-community collaborations for the twenty-first century: Outreach scholarship for youth and families. New York: Garland.

Meier, J. (1993). Notes from the underground: Integrating psychological and legal perspectives on domestic violence in theory and practice. Hofstra Law Review, 21, 1295-1366.

Merryman, M. (1993). A survey of domestic violence programs in legal education. New England Law Review, 28, 383-4.52.

Morgan, T., \& Rotunda, R. (2001). Model code of professional responsibility, model rules of professional conduct, and other selected standards including California, New York and Washington, D.C., rules on professional responsibility. Westbury, NY: Foundation Press.

Myers, K. (1993, October 4). Help for children. National Law Journal, p. 4.

National Association of Social Workers. (1999). Code of ethics. Retrieved June 13, 2002, from www.naswdc.org/pubs/code/default.asp

Peters, J. K. (1997). Representing children in child protective proceedings: Ethical and practical dimensions. Charlottesville, VA: LEXIS Law.

Ross, C. J. (1998). The failure of fragmentation: The promise of a system of unified family courts. Family Law Quarterly, 32, 1-30.

Ross, C. J. (1999, January). Unified family courts: Good sense, good justice. TRIAL, pp. 30-34.

St. Joan, J. (2001). Building bridges, building walls: Collaboration between lawyers and social workers in a domestic violence clinic and issues of confidentiality. Clinical Law Reviews, 7, 403-467.

Scarneccia, S. (1997). An interdisciplinary seminar in child abuse and neglect with a focus on child protection practice. Michigan Journal of Law Reform, 31, 33-56. 
Sicklick, J. E. (2001). MLPP turns 1-year-old: What we have meant to patients and families, Medical-Legal Partnership Highlights, 1(6). Retrieved June 13, 2002, from http://www.ccmckids.org/Families/0601 Highlights.pdf

Singleton, R. (1998, January 12). Disabled kids win back their SSI benefits. National Law Journal, p. B7.

Steiner, G. Y. (1981). The futility of family policy. Washington, DC: Brookings Institution.

Stolle, D. P. (1996). Professional responsibility in elder law: A synthesis of preventive law and therapeutic jurisprudence. Behavioral Science and Law, 14, 459-478.

Teitelbaum, L. E. (1996). The family as a system: A preliminary sketch. In 1996 Utah Law Review, 537- 568.

Virtue v. Wayne County Juvenile Court, 407 Mich. 1159 (1979).

Woodhouse, B. B. (1993). Mad midwifery: Bringing theory, doctrine and practice to life, Michigan Law Review, 91, 1977-1997.

Zotter, J. (2000). A holistic approach to helping families. ABA Child Law Practice, 19, 81-86. 